\title{
Performance of a modified alkaline lignin towards copper adsorption under different conditions
}

\author{
Chunli Zheng ${ }^{1,2^{+*}}$, Qiaorui Wang ${ }^{1^{*}}$, Yujie Dai ${ }^{3}$, Bo $\mathrm{Zu}^{4^{+}}$, Yangyang Zhang ${ }^{4}$ Tian C Zhang \\ ${ }^{1}$ Department of Environmental Science and Engineering, Xi'an Jiaotong University, Xi'an 710049, P.R. China \\ ${ }^{2}$ Key Laboratory of Thermo-Fluid Science and Engineering, Ministry of Education, Xi'an Jiaotong University, Xi'an 710049, P.R. China \\ ${ }^{3}$ Jiangsu TST professional testing Co., Ltd, Suqian 223800, Jiangsu, P.R. China \\ ${ }^{4}$ College of River and Ocean Engineering, Chongqing Jiaotong University, Chongqing 400074, P.R. China \\ ${ }^{5}$ Civil \& Environmental Engineering Department, University of Nebraska-Lincoln at Omaha Campus Omaha, NE 68182-0178, United States \\ "These authors contributed equally to this work.
}

\begin{abstract}
Polyethyleneimine and carbon disulfide were employed to modify alkaline lignin (AL) in order to introduce - $\mathrm{NH}_{\text {, }}-\mathrm{NH}_{2}$ and -CSS- groups. Its adsorption performance towards $\mathrm{Cu}(\mathrm{II})$ was evaluated based on the residual concentration $\left(C_{\mathrm{r}}\right)$ against the discharge permissible concentration for $\mathrm{Cu}$ (II) $(2.0 \mathrm{mg} / \mathrm{L})$ established by the World Health Organization. The evaluation was operated under different conditions such as adjusting the solution $\mathrm{pH}, \mathrm{Cu}(\mathrm{II})$ coexisting with $\mathrm{K}(\mathrm{I}), \mathrm{Na}(\mathrm{I}), \mathrm{Ca}(\mathrm{II})$ or $\mathrm{Mg}(\mathrm{II})$, changing the contact time $(t)$ and initial concentration of $\mathrm{Cu}(\mathrm{II})\left(\mathrm{C}_{0}\right)$, as well as regeneration. When $t$ and $C_{0}$ equaled to $180 \mathrm{~min}$ and $50 \mathrm{mg} / \mathrm{L}, C_{\mathrm{r}}$ was less than $2.0 \mathrm{mg} / \mathrm{L}$ at $\mathrm{pH}$ of 5.03 to 5.65 . Under the situation of $\mathrm{Cu}$ (II) coexisting with $50 \mathrm{mg} / \mathrm{L}$ of $\mathrm{K}(\mathrm{I}), \mathrm{Na}(\mathrm{I}), \mathrm{Ca}(\mathrm{II})$ or $\mathrm{Mg}(\mathrm{II}), C_{\mathrm{r}}$ was as low as $1.96,1.53,1.97$ or $1.55 \mathrm{mg} / \mathrm{L}\left(t=180 \mathrm{~min}, C_{0}=50 \mathrm{mg} / \mathrm{L}\right)$, respectively. Even the modified AL was regenerated and reused four times, $C_{\mathrm{r}}$ was closed to $2 \mathrm{mg} / \mathrm{L}$ for each time $\left(t=180 \mathrm{~min}, C_{0}=51 \mathrm{mg} / \mathrm{L}\right)$. By comparing with other lignin-based materials according to the adsorption equilibrium time, the maximum adsorption capacity, and $C_{\mathrm{r}}$, the modified $\mathrm{AL}$ exhibited higher application potential in copper-loaded water treatment.
\end{abstract}

Keywords: Adsorption, Binding interaction, $\mathrm{Cu}(\mathrm{II})$, Isotherm, Kinetics, Lignin

\section{Introduction}

Water body loaded with heavy metals is an important environmental problem due to the heavy metals could be bio-accumulated and further cause ecological damage [1]. Although copper is important to human beings, it also injures health at high concentration [2]. After enriching via food chain, the excess $\mathrm{Cu}$ (II) could be assimilated into human body and trigger various diseases of gastrointestinal discomfort, liver and kidney damage [3, 4]. The discharge permissible concentration for $\mathrm{Cu}(\mathrm{II})$ in drinking water is $2.0 \mathrm{mg} / \mathrm{L}$ according to the World Health Organization (WHO) [5]. In China, the three-level discharged concentration of $\mathrm{Cu}(\mathrm{II})$ from wastewater is ruled as $2.0 \mathrm{mg} / \mathrm{L}$ (GB 8978-1996). However, the concentrations of $\mathrm{Cu}(\mathrm{II})$ in most industrial wastewater far exceed $2.0 \mathrm{mg} / \mathrm{L}$. For example, the concentration of $\mathrm{Cu}(\mathrm{II})$ is approximately $50 \mathrm{mg} / \mathrm{L}$ discharged from electroplating industry [6] and $20 \mathrm{mg} / \mathrm{L}$ in washing water

This is an Open Access article distributed under the terms of the Creative Commons Attribution Non-Commercial License (http://creativecommons.org/licenses/by-nc/3.0/) which permits unrestricted non-commercial use, distribution, and reproduction in any medium, provided the original work is properly cited.

Copyright (C) 2022 Korean Society of Environmental Engineers of circuit board production [6]. Therefore, it is necessary to control the contamination of $\mathrm{Cu}(\mathrm{II})$ in the aquatic environment. By far, various approaches have been developed for removing heavy metals from aqueous solution, such as coagulation flocculation [7], precipitation filtration [8], solvent extraction [9], reverse-osmosis [10] and adsorption [11]. Of these technologies, adsorption could be used as a promising method, attributing to the advantages of easy accessibility and cost effectiveness [12]. Currently, considerable research has focused on designing and fabricating a series of adsorbents with chemical activity and versatile functional groups by using biomass as raw materials due to their extensive sources, environmental friendliness and low cost [13].

Lignin is the second largest biomass after cellulose in the nature $[14,15]$. As an industrial by-product, lignin is generated from pulping and bio-refinery on a large scale [16]. It was reported that approximately 70 million tons of lignin was produced from pulping

\footnotetext{
${ }^{\dagger}$ Corresponding author

E-mail: clzheng@xjtu.edu.cn; zubo@cqjtu.edu.cn Tel: +86 29 82663857; 862362650204

ORCID: 0000-0002-1518-5488; 0000-0003-0617-2957
}

Received February 19, 2021 Accepted May 01, 2021 
worldwide in 2017 [17, 18]. Lignin can be exploited as a kind of adsorbent for removing heavy metals from aqueous solution [17, 19-21], but before the practical use lignin needs to be modified. For instance, Zhang et al. [22] used monochloroacetic acid and amine reagents as modifiers to make lignin carry oxygen- and nitrogen-containing functional groups including hydroxy $(-\mathrm{OH})$, carboxyl $(-\mathrm{COOH})$ and amine $\left(-\mathrm{NH}_{2}\right)$. The modified lignin reduced 50 $\mathrm{mg} / \mathrm{L} \mathrm{Cu}$ (II) to $15 \mathrm{mg} / \mathrm{L}$ after $720 \mathrm{~min}$ [22]. Xu et al. [23] fabricated a kind of aminated lignin, in which amine substance was used to ornament lignin and consequently the nitrogen-containing groups of $-\mathrm{NH}$ and $-\mathrm{NH}_{2}$ were introduced; the aminated lignin reduced $50 \mathrm{mg} / \mathrm{L} \mathrm{Cu}$ (II) to $8.5 \mathrm{mg} / \mathrm{L}$ after $360 \mathrm{~min}$. Chakraborty and Tare [24] adopted xanthates to modify lignin with the functional groups of -CSS- and -COC, and then treated Cu(II)-loaded water $(20 \mathrm{mg} / \mathrm{L})$. After $720 \mathrm{~min}$, approximately $16 \mathrm{mg} / \mathrm{L}$ of $\mathrm{Cu}(\mathrm{II})$ was detected in aqueous solution. Although these modified lignins could remove a certain percentage of $\mathrm{Cu}$ (II), all the residual $\mathrm{Cu}(\mathrm{II})$ still exceeded the discharge standard of $2.0 \mathrm{mg} / \mathrm{L}$.

In our previous work, polyethyleneimine (PEI) and carbon disulfide $\left(\mathrm{CS}_{2}\right)$ were applied as the reagents to modify alkaline lignin (named as AL-PEI-CS ${ }_{2}$ ), in which -NH, - $\mathrm{NH}_{2}$ and -CSS- groups functionalized the network of alkaline lignin [25]. The removal efficiency of $\mathrm{Cu}(\mathrm{II})$ was investigated, in which seven metal ions including $\mathrm{Cu}(\mathrm{II}), \mathrm{Pb}(\mathrm{II}), \mathrm{Cd}(\mathrm{II}), \mathrm{Zn}(\mathrm{II}), \mathrm{Co}(\mathrm{II}), \mathrm{Ca}(\mathrm{II})$ and $\mathrm{Mg}$ (II) coexisted in aqueous solution $(\mathrm{pH}=6.0)$. All the initial concentrations for the seven ions were set at $2.0 \mathrm{mg} / \mathrm{L}$. After $300 \mathrm{~min}$, it was found that the residual concentration of $\mathrm{Cu}$ (II) was only $0.06 \mathrm{mg} / \mathrm{L}$, far below the discharge permissible concentration $(2 \mathrm{mg} / \mathrm{L})$. However, the adsorption mechanism of AL-PEI-CS 2 towards $\mathrm{Cu}$ (II) has not been studied systematically. In this work, the adsorption kinetics, adsorption isotherm, the binding interaction between $\mathrm{AL}-\mathrm{PEI}-\mathrm{CS}_{2}$ and $\mathrm{Cu}(\mathrm{II})$, as well as the reusing ability were investigated with the initial concentration of $\mathrm{Cu}$ (II) closed to that in real wastewater and the residual concentration of $\mathrm{Cu}$ (II) against WHO's standard. This work aims at preparing a kind of modified alkaline lignin for treatment of $\mathrm{Cu}$ (II)-loaded wastewater and providing an insight into the treatment of wastewater contaminated by heavy metals by the biomass-based adsorbent.

\section{Chemicals and Methods}

\subsection{Chemicals}

The analytical grade of AL was brought from Bailaibo Technology Co. LTD (Beijing, China). PEI (branched, $M_{\mathrm{w}}=70,000,30 \mathrm{w} / \mathrm{V}$ aqueous solution) was obtained from Shanghai Xinrui Biotechnology Co., LTD (Shanghai, China). Other analytical grade reagents of sodium hydroxide $(\mathrm{NaOH})$, hydrochloric acid $(\mathrm{HCl})$, formaldehyde (HCHO), $\mathrm{CS}_{2}$ and ethanol were all provided by Chongqing Zinguang Chemical Co. LTD (Chongqing, China). Standard solutions (all in 1,000 mg/L) of copper nitrate $\left(\mathrm{Cu}\left(\mathrm{NO}_{3}\right)_{2}\right)$, potassium nitrate $\left(\mathrm{KNO}_{3}\right)$, calcium nitrate $\left(\mathrm{Ca}\left(\mathrm{NO}_{3}\right)_{2}\right)$, sodium nitrate $\left(\mathrm{NaNO}_{3}\right)$ and magnesium nitrate $\left(\mathrm{Mg}\left(\mathrm{NO}_{3}\right)_{2}\right)$ were all supplied by the Guangzhou Analysis test center Keli Technology Development Co. LTD (Guangdong, China). Ultrapure water was prepared from a FAMO-10 equipment (resistivity $=18.25 \mathrm{~m} \Omega-\mathrm{cm}$, Nanjing
Quankun Biotechnology Co. LTD, China).

\subsection{Preparation of $\mathrm{AL}-\mathrm{PEI}-\mathrm{CS}_{2}$ and Characterization}

The modified alkaline lignin, named as AL-PEI-CS ${ }_{2}$, was prepared via the same method as described in our previous work [25]. AL was employed as the raw material and two reagents (PEI and $\mathrm{CS}_{2}$ ) as the modifiers in order to introduce nitrogen- and sulfur- containing functional groups. Briefly, three grams of AL were dissolved into $90 \mathrm{~mL}$ of ultrapure water in a $300-\mathrm{mL}$ three-neck flask. The solution $\mathrm{pH}$ was adjusted at 13.0 via $0.1 \mathrm{~mol} / \mathrm{L}$ of $\mathrm{NaOH}$. The flask was placed on a magnetic stirring apparatus for agitating $30 \mathrm{~min}$ at room temperature. Ten milliliters of HCHO and $10 \mathrm{~mL}$ of PEI were dropwise added into the flask, in which the temperature of the apparatus was set at $90^{\circ} \mathrm{C}$ for sustaining $5 \mathrm{~h}$ and then cooled to $40^{\circ} \mathrm{C} . \mathrm{CS}_{2}(15 \mathrm{~mL})$ was added into the flask drop by drop. After $3 \mathrm{~h}$, the precipitates in the flask were collected by centrifugation (TD-4M, Jinan Oulaibo Scientific Instrument Co., Ltd, China) at $5,000 \mathrm{rpm}$ and $25^{\circ} \mathrm{C}$. Ethanol and ultrapure water were used for washing the precipitates until the filtrate $\mathrm{pH}$ ranged from 6.0 to 7.0. The precipitates were dried via vacuum freeze dryer (FD-1A-50, Jiangsu Tianling Instrument Co., Ltd, China) at $-60^{\circ} \mathrm{C}$ for $6 \mathrm{~h}$. Finally, a kind of red-brown powders was obtained $\left(\mathrm{AL}-\mathrm{PEI}-\mathrm{CS}_{2}\right)$ and stored in a centrifuge tube $(\Phi=2.5 \mathrm{~cm}$, Jinan Oulaibo Electronic Commerce Co., Ltd) at room temperature for further use.

The morphology of AL and AL-PEI-CS 2 (coated with $\mathrm{Au}$ powders) was analyzed through scanning electron microscope energy (VEGAIIXMU, Germany) coupled with dispersive spectroscopy (OXFORD, England) (SEM-EDS). Fourier transform infrared spectroscopy (FT-IR) (Nicolet NEXUS 750, USA) was operated under the condition of resolution $4 \mathrm{~cm}^{-1}$ and scans number 16. X-ray photoelectron spectroscopy (XPS) spectra was run by using Mg and $\mathrm{K} \alpha$ as X-ray sources (1253.6 eV protons) (Thermo Scientific K-Alpha, USA). All the binding energies of XPS spectra were calibrated based on $\mathrm{C}$ 1s at $284.6 \mathrm{eV}$. Zeta potential (Malvern Zetasizer Nano S90, England) was conducted by adding $10 \mathrm{mg}$ of AL-PEI-CS ${ }_{2}$ into $10 \mathrm{~mL}$ of aqueous solutions ( $\mathrm{pH}=1.0,3.0,4.0,5.0,6.0$ and 9.0); after ultrasonic for $1 \mathrm{~h}$ and standing for $24 \mathrm{~h}$, the samples of the solutions were measured. The specific surface areas were analyzed at $77 \mathrm{~K}$ via $\mathrm{N}_{2}$ adsorption-desorption isotherms (ASAP2460, McMuratik Instrument Co., Ltd, USA).

\subsection{Adsorption Performance Evaluation}

\subsubsection{Monitoring the residual concentration of $\mathrm{Cu}(\mathrm{II})$ at different} solution $\mathrm{pH}$

The initial concentration of $\mathrm{Cu}(\mathrm{II})$ was $50 \mathrm{mg} / \mathrm{L}$. The values of solution $\mathrm{pH}$ varied from 1.0 to 6.0 adjusting by $0.1 \mathrm{~mol} / \mathrm{L}$ of $\mathrm{HCl}$ or $\mathrm{NaOH}$. Fifty milliliters of $\mathrm{Cu}(\mathrm{II})$ solution and $0.0500 \mathrm{~g}$ of AL-PEI-CS ${ }_{2}$ were put into a $250-\mathrm{mL}$ conical flask, and then covered with parafilm (Huimin Tengjie Plastic Industry Co. Ltd, China). The flasks were placed on a shaker (HYQ45, Wuhan Huicheng Biological Technology CO. Ltd, China) at $25^{\circ} \mathrm{C}$ and $140 \mathrm{rpm}$. After $180 \mathrm{~min}, 5 \mathrm{~mL}$ of sample was withdrawn (Finnpipette ${ }^{\mathrm{TM}} \mathrm{F} 1$, Thermo Fisher Scientific Co., Ltd, USA) and passed through $0.45 \mu \mathrm{m}$ nylon membrane filter (Guangzhou Tongpu Experimental Instrument Co., Ltd, China). The filtrate was collected for monitoring the residual concentration of $\mathrm{Cu}(\mathrm{II})$ via the inductively coupled plasma optical 
emission spectrometry (ICP-OES) (Thermo, USA). Three parallel tests were carried out and error bars were used to analyze the data depicting 95\% confidence intervals. The control experiments were performed in the absence of AL-PEI-CS ${ }_{2}$ to determine if the loss in $\mathrm{Cu}$ (II) happened through other pathways (e.g., adsorption on the flask wall, evaporation, or sorbed by the filter paper).

\subsubsection{Monitoring the residual concentration of $\mathrm{Cu}(\mathrm{II})$ at the presence of cations}

Four cations of $\mathrm{K}(\mathrm{I}), \mathrm{Na}(\mathrm{I}), \mathrm{Ca}(\mathrm{II})$ and $\mathrm{Mg}(\mathrm{II})$ were used. As for each cation, 2.5 or $5 \mathrm{~mL}$ of standard solution $(1,000 \mathrm{mg} / \mathrm{L})$ was mixed with $\mathrm{Cu}$ (II) solution $(2.5 \mathrm{~mL}, 1,000 \mathrm{mg} / \mathrm{L})$ in a $250-\mathrm{mL}$ conical flask. The mixed aqueous solution was diluted to be $50 \mathrm{~mL}$ with adjusted $\mathrm{pH}$ as 5.03, in which $C_{0}$ of $\mathrm{Cu}$ (II) was obtained as 50 $\mathrm{mg} / \mathrm{L}$. The value of $C_{0}$ for each cation was 50 and $100 \mathrm{mg} / \mathrm{L}$, respectively. Then $0.0500 \mathrm{~g}$ of AL-PEI-CS ${ }_{2}$ was added into the flask for the adsorption experiments. Three parallel tests were carried out and error bars were used to analyze the data depicting $95 \%$ confidence intervals. Other operations were the same as those mentioned in Section 2.3.1.

\subsubsection{Monitoring the residual concentration of $\mathrm{Cu}(\mathrm{II})$ under different contact times and initial concentrations}

Fifty milliliters of $\mathrm{Cu}(\mathrm{II})$ solutions $(5,10,15,20,30$ and $50 \mathrm{mg} / \mathrm{L})$ and $0.0500 \mathrm{~g}$ of $\mathrm{AL}-\mathrm{PEI}-\mathrm{CS}_{2}$ were put into a $250-\mathrm{mL}$ conical flask, respectively. All the solution $\mathrm{pH}$ values were set at 5.03. The flasks were placed on a shaker at $25^{\circ} \mathrm{C}$ and $140 \mathrm{rpm}$. At certain intervals, $5 \mathrm{~mL}$ of the sample was withdrawn. Three parallel tests were carried out and error bars were used to analyze the data depicting 95\% confidence intervals. Other operations were the same as those mentioned in Section 2.3.1.

Adsorption kinetics and isotherm were shown in Text S1 in the Supplementary Materials (SI).

\subsubsection{Monitoring the residual concentration of $\mathrm{Cu}(\mathrm{II})$ during the regeneration process}

Fifty milliliters of $\mathrm{Cu}(\mathrm{II})$ solution $\left(C_{0}=51 \mathrm{mg} / \mathrm{L}, \mathrm{pH}=5.03\right)$ and $0.0500 \mathrm{~g}$ of AL-PEI-CS ${ }_{2}$ were added into a $250-\mathrm{mL}$ conical flask and then covered with parafilm. The flask was placed into a shaker at $25^{\circ} \mathrm{C}$ and $140 \mathrm{rpm}$. After $180 \mathrm{~min}$, all the things in the flask were poured out and passed through filter paper (Eco Safety Technology Co., Ltd, China) for collecting Cu(II)-loaded AL-PEI-CS ${ }_{2}$ powder. Ultrapure water was used to wash $\mathrm{Cu}$ (II)-loaded AL-PEI-CS powder until no detection of $\mathrm{Cu}$ (II) in filtrate. $\mathrm{Cu}$ (II)-loaded AL-PEI-CS 2 powder was dried in air for $12 \mathrm{~h}$ at ambient temperature $\left(\sim 25^{\circ} \mathrm{C}\right)$ and then used for monitoring the residual concentration of $\mathrm{Cu}(\mathrm{II})$ during the regeneration process and adsorption mechanism, respectively.

For monitoring the residual concentration of $\mathrm{Cu}(\mathrm{II})$ during the regeneration process, the $\mathrm{Cu}(\mathrm{II})$-loaded $\mathrm{AL}-\mathrm{PEI}-\mathrm{CS}_{2}$ powder was mixed with $50 \mathrm{~mL}$ of $\mathrm{HCl}$ solution $(0.2 \mathrm{~mol} / \mathrm{L})$ in a $250-\mathrm{mL}$ conical flask under $140 \mathrm{rpm}$ at $25^{\circ} \mathrm{C}$ for regeneration. After $180 \mathrm{~min}$, all the things in the flask were poured out and passed through filter paper for collecting the regenerated powder. Ultrapure water was used to wash the regenerated powder until filtrate $\mathrm{pH}$ was in the range of 5.0 to 6.0 . Then the regenerated powder $(0.0500 \mathrm{~g})$ was mixed with $50 \mathrm{~mL}$ of $\mathrm{Cu}(\mathrm{II})$ solution $\left(C_{0}=51 \mathrm{mg} / \mathrm{L}, \mathrm{pH}=5.03\right)$ in a-250 mL conical flask. The conical flask was covered with parafilm and shaken at $25^{\circ} \mathrm{C}$ and $140 \mathrm{rpm}$. After $180 \mathrm{~min}$, the sample was withdrawn with $5 \mathrm{~mL}$ pipette and filtered through $0.45 \mu \mathrm{m}$ nylon membrane. The filtrate was used for the analysis of residual $\mathrm{Cu}$ (II) concentration. The number for the adsorption-desorption cycle was four. Three parallel tests were carried out and error bars were used to analyze the data depicting $95 \%$ confidence intervals.

$$
\text { Decrease ratio }=\left(q_{\mathrm{e}}^{\text {Fresh }}-q_{\mathrm{e}}^{\mathrm{n}}\right) / q_{\mathrm{e}}^{\text {Fresh }} \times 100 \%
$$

where $q_{\mathrm{e}}^{\mathrm{Fresh}}(\mathrm{mg} / \mathrm{g})$ is the equilibrium adsorption capacity of $\mathrm{Cu}(\mathrm{II})$ for fresh AL-PEI-CS ${ }_{2} ; q_{\mathrm{e}}^{\mathrm{n}}(\mathrm{mg} / \mathrm{g})$ is the equilibrium adsorption capacity for regenerated AL-PEI-CS ${ }_{2}$ at each cycle.

\subsection{Adsorption Mechanism}

$\mathrm{Cu}$ (II)-loaded AL-PEI-CS $\mathrm{S}_{2}$ powder (AL-PEI-CS ${ }_{2}-\mathrm{Cu}(\mathrm{II})$ complexes) was analyzed by SEM-EDS, FT-IR and XPS. The powder was ground and squashed with $\mathrm{KBr}$ pellets for FT-IR spectra with resolution being $4 \mathrm{~cm}^{-1}$ and scans number being 16. XPS used $\mathrm{Mg}$ and $\mathrm{K} \alpha$ as X-ray sources (1,253.6 eV protons). The experimental steps can be seen from Section 2.3.4.

\subsection{Calculation}

The adsorption capacity $\left(q_{\mathrm{t}}\right)$ and removal efficiency (\%) of $\mathrm{Cu}(\mathrm{II})$ were calculated by the following equations:

$$
\begin{gathered}
q_{\mathrm{t}}=\frac{\left(C_{0}-C_{r}\right)}{M} \times V \\
\text { Removal efficiency }(\%)=\frac{C_{0}-C_{\mathrm{r}}}{C_{0}} \times 100 \%
\end{gathered}
$$

where $C_{0}(\mathrm{mg} / \mathrm{L})$ is initial concentration of $\mathrm{Cu}(\mathrm{II}) ; C_{r}(\mathrm{mg} / \mathrm{L})$ is the residual concentration of $\mathrm{Cu}(\mathrm{II})$ at time $t ; V(\mathrm{~L})$ and $M(\mathrm{~g})$ are the volumes of $\mathrm{Cu}$ (II) solution and the mass of AL-PEI-CS ${ }_{2}$, respectively.

\section{Results and Discussion}

\subsection{Characterization of the Modified Alkaline Lignin}

As presented in Fig. S1(a), the color of the raw AL was black while changed into yellow-brown after modification. SEM pictures exhibited that $\mathrm{AL}$ was composed of large blocks whereas the particles of AL-PEI-CS ${ }_{2}$ were relatively small and incompact (Fig. S1(b)). According to $\mathrm{N}_{2}$ absorption-desorption isotherm (Fig. S1(c)), the BET specific area of AL-PEI-CS ${ }_{2}$ was calculated to be $1.656 \mathrm{~m}^{2} / \mathrm{g}$, almost 16 times higher than that of raw $\mathrm{AL}\left(0.102 \mathrm{~m}^{2} / \mathrm{g}\right)$. FT-IR spectra displays that $\mathrm{AL}$ contained the functional groups of $-\mathrm{OH}$ $\left(3,431 \mathrm{~cm}^{-1}\right)$ [19] and -OCH/H-C-H $\left(2,935 / 2,840 \mathrm{~cm}^{-1}\right)$ [26] as well as aromatic ring skeleton $\left(1,592 / 1,509 \mathrm{~cm}^{-1}\right.$ ) [27] (Fig. 1(a)). As for AL-PEI-CS ${ }_{2}$, four new peaks corresponding to $-\mathrm{NH}_{2}\left(1,662 \mathrm{~cm}^{-1}\right)$ [28], C-N (1,366 $\left.\mathrm{cm}^{-1}\right)$ [29], $\mathrm{C}=\mathrm{S}\left(1,081 \mathrm{~cm}^{-1}\right)$ [30] and C-S (855 $\mathrm{cm}^{-1}$ ) [31] were recorded. In addition, the stretching vibration of -NH can also be discovered at $3,431 \mathrm{~cm}^{-1}$ for AL-PEI-CS 2 [19]. Besides FT-IR, the technology of XPS was adopted. Fig. 1(b) shows full scan survey XPS spectra for AL and AL-PEI-CS ${ }_{2}$. Different 

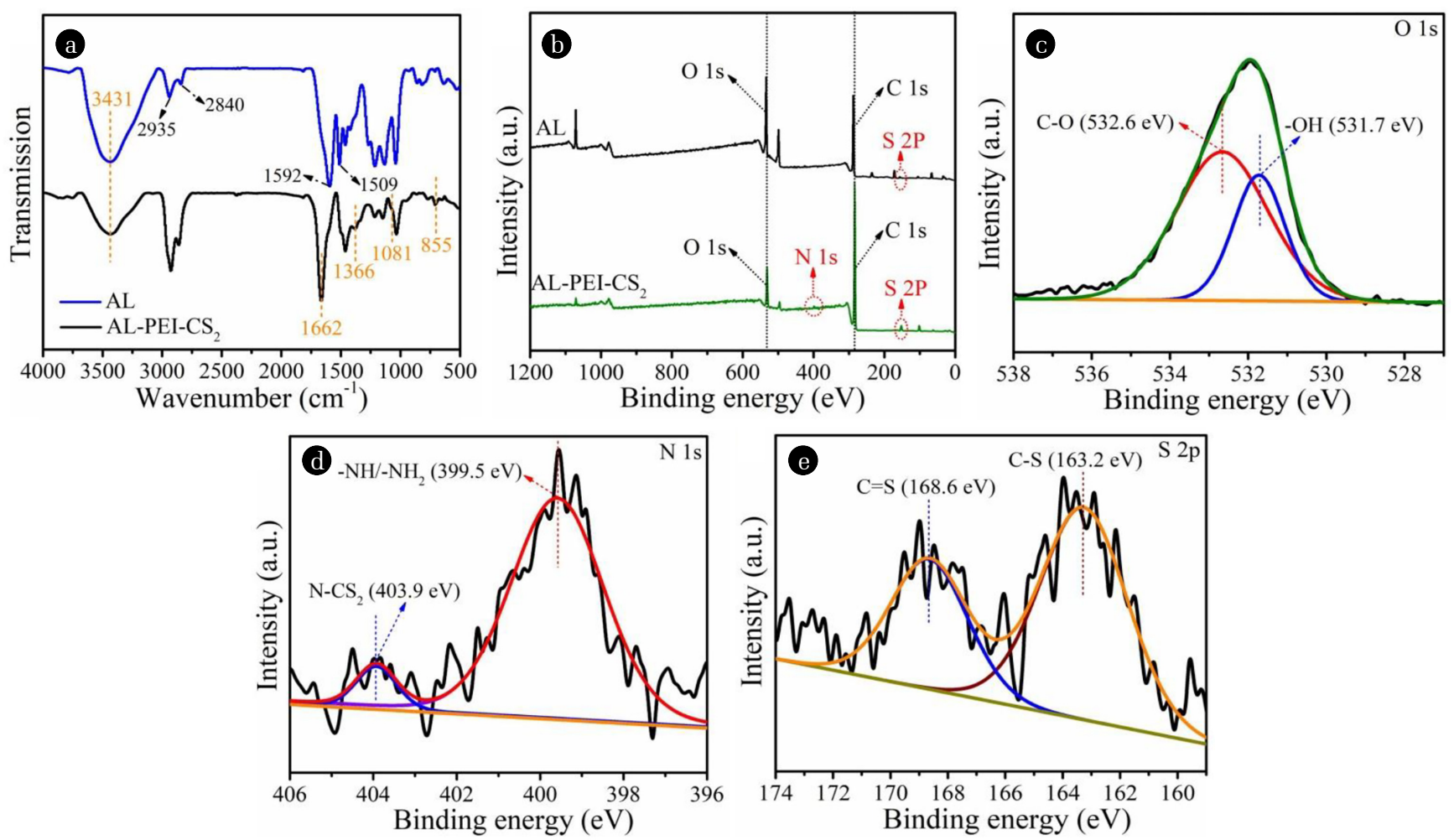

Fig. 1. (a) FT-IR spectra of $A L$ and AL-PEI-CS ${ }_{2}$; (b) full scan survey XPS spectra of AL and AL-PEI-CS ${ }_{2}$; high resolution XPS spectra of AL-PEI-CS 2 : (c) $\mathrm{O} 1 \mathrm{~s}$, (d) $\mathrm{N}$ 1s, and (e) $\mathrm{S} 2 \mathrm{p}$.

from the three peaks of $\mathrm{C} 1 \mathrm{~s}, \mathrm{O} 1 \mathrm{~s}$ and $\mathrm{S} 2 \mathrm{p}$ carried by $\mathrm{AL}$, one new peak of $\mathrm{N}$ 1s was detected in AL-PEI-CS 2 (Fig. 1(b)). As for the discovery of $\mathrm{S} 2 \mathrm{p}$ in $\mathrm{AL}$, it was due to the usage of sodium sulfide $\left(\mathrm{Na}_{2} \mathrm{~S}\right)$ during its preparation [20]. As depicted in Fig. 1(c), the spectra of $\mathrm{O} 1 \mathrm{~s}$ were determined as $\mathrm{C}-\mathrm{O}(532.6 \mathrm{eV})$ [32] and $\mathrm{O}-\mathrm{H}(531.7 \mathrm{eV})$ [32]. According to Fig. 1(d), N 1s spectra corresponded to $\mathrm{N}^{-\mathrm{CS}_{2}}(403.9 \mathrm{eV})[33,34]$ and $-\mathrm{NH} /-\mathrm{NH}_{2}(399.5 \mathrm{eV})$ [19]. Fig. 1(e) was the binding energy of $S 2 p$, which belonged to $\mathrm{C}=\mathrm{S}(168.6 \mathrm{eV})$ [33] and C-S (163.2 eV) [33]. Considering the results from FT-IR and XPS, the nitrogen-, sulfur- and oxygen-containing groups of the modified alkaline lignin were determined as $-\mathrm{OH}$, - $\mathrm{NH}$, $-\mathrm{NH}_{2}$, and $-\mathrm{S}-\mathrm{C}=\mathrm{S}$ - (-CSS-), which would serve as the adsorption sites for removal of metal ions from aqueous solution.

\subsection{Evaluation on Adsorption Performance of the Modified Alkaline Llignin}

3.2.1. Residual concentration of $\mathrm{Cu}(\mathrm{II})$ at different solution $\mathrm{pH}$ As for effluent discharged from mine wastewater, electroplating wastewater and washing water of circuit board production, the $\mathrm{pH}$ value generally ranges from 2.0 to 5.0 [35]. Therefore, the solution $\mathrm{pH}$ in this study was set at 1.0 to 6.0. As seen from zeta potential curve (Fig. 2(a)), surface of the modified alkaline lignin (AL-PEI-CS $)_{2}$ would be positively charged at solution $\mathrm{pH}<3.1$ while negatively charged at solution $\mathrm{pH}>3.1$ (pHpzc $=3.1$ ). Fig. 2(b) exhibits the dissociation forms of copper at different solution $\mathrm{pH}$ values, in which $\mathrm{Cu}^{2+}$ ions exist as the main species accompanied by a little amount of $\mathrm{CuOH}^{+}$ions when $\mathrm{pH}$ value is less than 6.0. It can be assumed that electrostatic attraction would occur between AL-PEI-CS ${ }_{2}$ and $\mathrm{Cu}(\mathrm{II})$ when the solution $\mathrm{pH}$ varies from 3.1 to 6.0. The higher solution $\mathrm{pH}$ is, the stronger the electrostatic attraction happens. The adsorption ability of AL-PEI-CS ${ }_{2}$ towards $\mathrm{Cu}(\mathrm{II})$ is supposed to follow the sequence (in $\mathrm{pH}$ ) of $6.0>5.0>4.0$ $>3.0>1.0$. In order to verify such a sequence, the adsorption experiments for $\mathrm{Cu}$ (II) over AL-PEI-CS $\mathrm{C}_{2}$ at different $\mathrm{pH}$ values were conducted.

As displayed in the insert of Fig. 2(a), the adsorption capacity $\left(q_{\mathrm{t}}\right)$ and the removal efficiency was $45 \mathrm{mg} / \mathrm{g}$ and $92 \%$ for $\mathrm{Cu}(\mathrm{II})$ at $\mathrm{pH}$ of 1.30 and then increased to $49 \mathrm{mg} / \mathrm{g}$ and $98 \%$ at $\mathrm{pH}$ of 5.65 when the initial concentration $\left(C_{0}\right)$ of $\mathrm{Cu}(\mathrm{II})$ was $50 \mathrm{mg} / \mathrm{L}$ and the contact time was $180 \mathrm{~min}$, respectively. The possible reason for this result was the excess protons $\left(\mathrm{H}^{+}\right)$resulted in the protonation of the functional groups carried by AL-PEI-CS ${ }_{2}$ at lower $\mathrm{pH}$, and consequently the electronic attraction between $\mathrm{Cu}^{2+}$ ions and AL-PEI-CS 2 weakened, whereas the deprotonation occurred to improve the adsorption at a higher $\mathrm{pH}$ value [36, 37].

In order to verify the change in solution $\mathrm{pH}$ before and after adsorption, the values of $\mathrm{pH}_{\text {initial }}$ were set as $1.30,3.15,4.14,5.03$ and 5.65. When $\mathrm{pH}_{\text {initial }}$ equaled to 1.30 , the value of $\mathrm{pH}_{\text {final }}$ was measured to be 1.33 (insert in Fig. 2(b)). As shown in Fig. 2(a), at the condition of $\mathrm{pH}$ lower than pHpzc (3.1), the surface of AL-PEI-CS ${ }_{2}$ is charged positively, which means that $\mathrm{H}^{+}$pronated the functional groups of $-\mathrm{OH},-\mathrm{NH},-\mathrm{NH}_{2}$ and -CSS- [36, 37] and consequently the amount of protons in solution decreased. This 

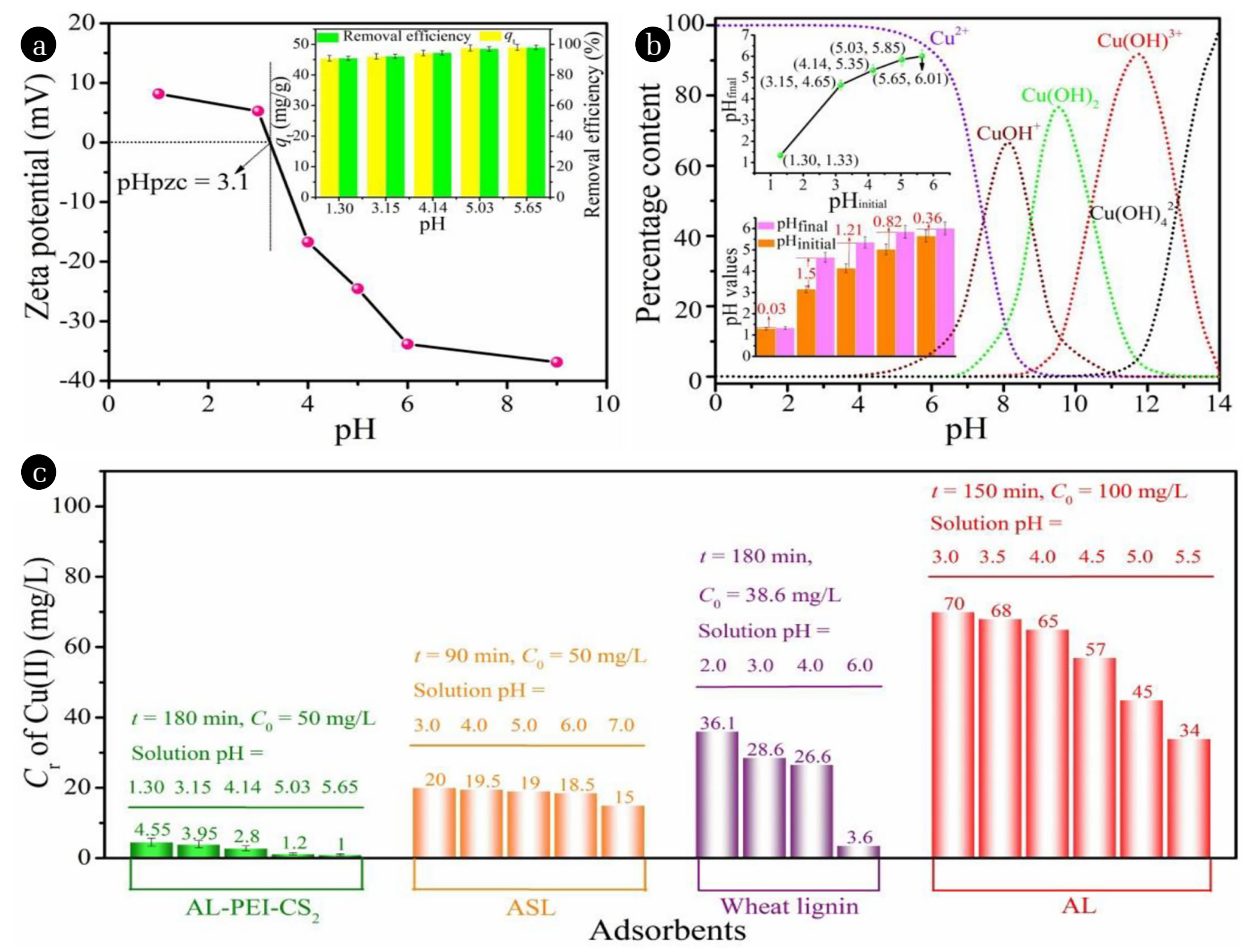

Fig. 2. (a) Zeta potential of AL-PEI-CS (insert: the effect of solution $\mathrm{pH}$ on the adsorption performance); (b) speciation of Cu(II) at different $\mathrm{pH}$ values [37] (insert: the changes in $\mathrm{pH}$ values before and after adsorption); and (c) the residual concentration $\left(\mathrm{C}_{\mathrm{r}}\right)$ of $\mathrm{Cu}(\mathrm{II})$ treated via ASL [19], wheat lignin [38] and AL [23] at different solution $\mathrm{pH}$ values.

might explain why the value of $\mathrm{pH}_{\text {final }}$ (1.33) was higher than that of $\mathrm{pH}_{\text {initial }}$ (1.30). When $\mathrm{pH}_{\text {initial }}$ was set at $3.15,4.14,5.03$ and 5.65, the values of $\mathrm{pH}_{\text {final }}$ ascended to $4.65,5.35,5.85$ and 6.01 . The possible reason is that at the condition of $\mathrm{pH}$ higher than pHpzc (3.1) the negatively charged AL-PEI-CS $S_{2}$ would interact with proton via electronic attraction, and therefore, result in the increase in $\mathrm{pH}_{\text {final. }}$. Interestingly, the difference between $\mathrm{pH}_{\text {final }}$ and $\mathrm{pH}_{\text {initial }}$ was 1.5, 1.21, 0.82 and 0.36 (insert in Fig. 2(b)), suggesting more protons retained in solution at higher $\mathrm{pH}_{\text {initial. }}$ The decreasing trend might attribute to increasing $\mathrm{CuOH}^{+}$amounts at relatively higher initial solution $\mathrm{pH}$ (Fig. 2(b)). $\mathrm{CuOH}^{+}$might compete with proton and interact with AL-PEI-CS ${ }_{2}$.

The residual concentration of $\mathrm{Cu}(\mathrm{II})\left(C_{\mathrm{r}}\right)$ was measured to be 4.55, 3.95, 2.8, 1.2 and $1.0 \mathrm{mg} / \mathrm{L}$ corresponded to solution $\mathrm{pH}$ of $1.30,3.15,4.14,5.03$ and 5.65. It was discovered that when solution $\mathrm{pH}$ was limited in the range of 5.03 to 5.65 , the residual concentration of $\mathrm{Cu}(\mathrm{II})$ in the effluent can meet with the standard of $2 \mathrm{mg} / \mathrm{L}$ regulated by WHO and Chinese government. Ge et al. [19] adopted a kind of amino and sulfonic ornamented lignin (ASL) as the adsorbent, in which the removal efficiency of $\mathrm{Cu}(\mathrm{II})$ was $60 \%, 61 \%, 62 \%$, $63 \%$ and $70 \%$ when the value of solution $\mathrm{pH}$ was $3.0,4.0,5.0$, 6.0 and 7.0 (Fig. 2(c)), respectively. Accordingly, the $C_{\mathrm{r}}$ value of $\mathrm{Cu}(\mathrm{II})$ at $90 \mathrm{~min}$ was 20, 19.5, 19, 18.5 and $15 \mathrm{mg} / \mathrm{L}$ with $C_{0}$ of $50 \mathrm{mg} / \mathrm{L}$ (Fig. 2(c)) [19]. Todorciuc et al. [38] employed the raw lignin derived from wheat straw to adsorb $\mathrm{Cu}(\mathrm{II})\left(C_{0}=38.6 \mathrm{mg} / \mathrm{L}\right)$ (Fig. 2(c)). The residual concentration was 36.1, 28.6, 26.6 and $3.6 \mathrm{mg} / \mathrm{L}$ with solution $\mathrm{pH}$ being 2.0, 3.0, 4.0 and 6.0 as well as $t$ being 180 min (Fig. 2(c)) [38], respectively. Xu et al. [23] used a kind of aminated lignin (AL) to remove $\mathrm{Cu}$ (II) from water. The value of $C_{\mathrm{r}}$ for $\mathrm{Cu}$ (II) at $150 \mathrm{~min}$ was detected to be approximately $70,68,65,57,45$ and $34 \mathrm{mg} / \mathrm{L}$ corresponded to the solution $\mathrm{pH}$ of $3.0,3.5,4.0,4.5,5.0$ and 5.5 as $C_{0}$ of $\mathrm{Cu}(\mathrm{II})$ was $100 \mathrm{mg} / \mathrm{L}$ (Fig. 2(c)), respectively. As seen from these results, it can be concluded that the removal ability of AL-PEI-CS ${ }_{2}$ for $\mathrm{Cu}$ (II) is ideal at a wide $\mathrm{pH}$ range from 1.0 to 6.0 , especially at $\mathrm{pH}$ of 5.0 and 6.0 .

3.2.2. Residual concentration of $\mathrm{Cu}(\mathrm{II})$ at the presence of cations The influences of $\mathrm{K}(\mathrm{I}), \mathrm{Na}(\mathrm{I}), \mathrm{Ca}(\mathrm{II})$ and $\mathrm{Mg}(\mathrm{II})$ on the removal of $\mathrm{Cu}$ (II) by AL-PEI-CS ${ }_{2}$ were conducted as these cations naturally exist in the aqueous environment. As displayed in Fig. S2, the dominant speciation of $\mathrm{K}(\mathrm{I}), \mathrm{Na}(\mathrm{I}), \mathrm{Ca}(\mathrm{II})$ and $\mathrm{Mg}(\mathrm{II})$ is $\mathrm{K}^{+}, \mathrm{Na}^{+}$, $\mathrm{Ca}^{2+}$ and $\mathrm{Mg}^{2+}$ when solution $\mathrm{pH}$ is less than 8.0, respectively. These cations might compete with $\mathrm{Cu}(\mathrm{II})$ during the adsorption process. In this research, the initial concentrations of $\mathrm{K}(\mathrm{I}), \mathrm{Na}(\mathrm{I})$, $\mathrm{Ca}(\mathrm{II})$ and $\mathrm{Mg}(\mathrm{II})$ were set at 0,50 and $100 \mathrm{mg} / \mathrm{L}$ since these ions exist in the natural aqueous environment with the concentration of 0.2 to $167.4 \mathrm{mg} / \mathrm{L}$ [39]. Fig. S3 shows that the removal capacity of AL-PEI-CS 2 towards $\mathrm{Cu}(\mathrm{II})$ was not obviously affected by $\mathrm{K}(\mathrm{I}), \mathrm{Ca}(\mathrm{II}), \mathrm{Na}(\mathrm{I})$ and $\mathrm{Mg}(\mathrm{II})$. Even coexisted with the four cations, all the residual concentrations of $\mathrm{Cu}(\mathrm{II})$ almost meet with the standard of $2.0 \mathrm{mg} / \mathrm{L}$ regulated by WHO and Chinese government (Fig. 3(a)).

Fig. 3(a) compares the $\mathrm{Cu}(\mathrm{II}) C_{\mathrm{r}}$ between AL-PEI-CS${ }_{2}$ and nanotubes synthesized by Liu et al. [40]. It was found that when the initial concentrations of these cations, the initial concentration 


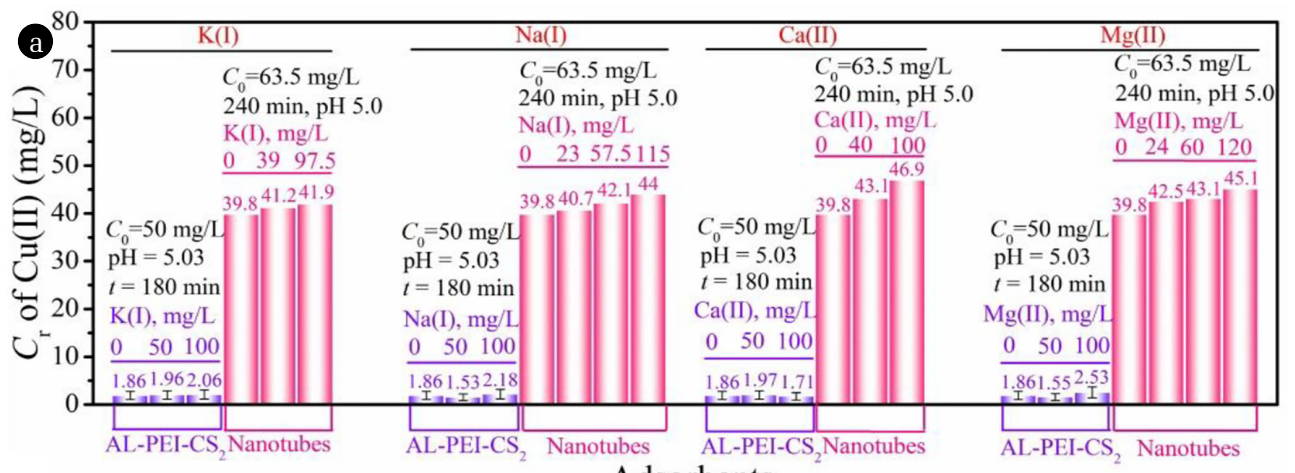

Adsorbents

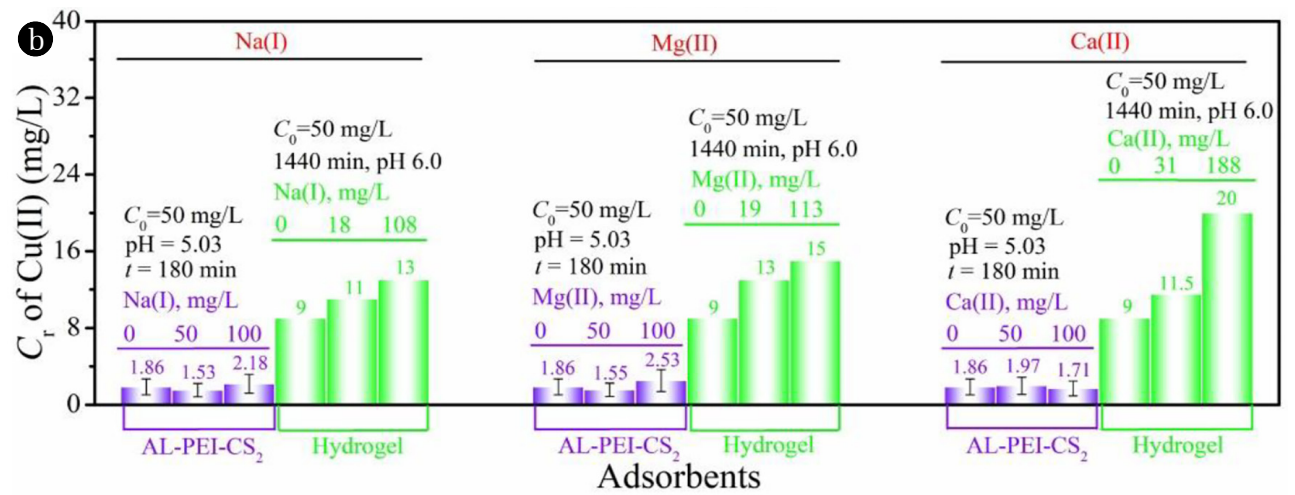

Fig. 3. (a) Comparison of $C_{r}$ between AL-PEI-CS $S_{2}$ and Nanotubes [40] at the presence of different cations; and (b) comparison of $C_{r}$ between $\mathrm{AL}-\mathrm{PEI}-\mathrm{CS}_{2}$ and Hydrogel [41] at the presence of different cations.

of $\mathrm{Cu}$ (II) and the contact time were close, the $\mathrm{Cu}$ (II) $C_{\mathrm{r}}$ for nanotubes were almost 20 to 30 times higher than those for AL-PEI-CS and far beyond the discharged standard of $2 \mathrm{mg} / \mathrm{L}$. Similar phenomenon was also observed for hydrogel prepared by Zhang et al. [41] (Fig. 3(b)).

As for the three adsorbents (AL-PEI-CS ${ }_{2}$, nanotubes and hydrogel), the monovalent cations including $\mathrm{Na}(\mathrm{I})$ and $\mathrm{K}(\mathrm{I})$ slightly affected the value of $C_{\mathrm{r}}$ while the influences of bivalent cations such as $\mathrm{Ca}$ (II) and $\mathrm{Mg}$ (II) were higher. The hydration free energy follows the order of $\mathrm{K}^{+}(-1,095 \mathrm{~kJ} / \mathrm{mol})>\mathrm{Na}^{+}(-1,097 \mathrm{~kJ} / \mathrm{mol})>\mathrm{Ca}^{2+}(-1,588$ $\mathrm{kJ} / \mathrm{mol})>\mathrm{Mg}^{2+}(-1,900 \mathrm{~kJ} / \mathrm{mol})[42,43]$. Cheng et al. [44] pointed out that higher hydration free energy tends to keep metal ions in aqueous solution, that is, prevents the transfer of the ions from bulk solution to the adsorbent surface. Therefore, $\mathrm{Ca}$ (II) and $\mathrm{Mg}$ (II) are easier to attach on the surfaces of AL-PEI-CS ${ }_{2}$, nanotubes and hydrogel than $\mathrm{Na}(\mathrm{I})$ and $\mathrm{K}(\mathrm{I})$, and consequently, competition of bivalent cations for adsorption would be more fierce.

\subsubsection{Residual concentration of Cu(II) under different contact times and initial concentrations}

Fig. 4(a) shows that all the values of adsorption capacity $\left(q_{t}\right)$ increased significantly from 0 to $60 \mathrm{~min}$ and then slightly from 60 to $120 \mathrm{~min}$. After $120 \mathrm{~min}$, the values of $q_{\mathrm{t}}$ kept almost unchanged even the contact time was prolonged to $180 \mathrm{~min}$. The equilibrium time was determined as $180 \mathrm{~min}$. According to the insert in Fig. 4(a), the adsorption efficiencies of $\mathrm{Cu}(\mathrm{II})$ over AL-PEI-CS ${ }_{2}$ reached 93\% ( $\left.C_{0}=5 \mathrm{mg} / \mathrm{L}\right), 95 \%\left(C_{0}=10 \mathrm{mg} / \mathrm{L}\right), 95 \%\left(C_{0}=15 \mathrm{mg} / \mathrm{L}\right)$, 95\% $\left(C_{0}=20 \mathrm{mg} / \mathrm{L}\right), 94 \%\left(C_{0}=30 \mathrm{mg} / \mathrm{L}\right)$, and $96 \%\left(C_{0}=50\right.$ $\mathrm{mg} / \mathrm{L}$ ) at $180 \mathrm{~min}$, respectively. The values of $C_{\mathrm{r}}$ was observed to be as low as 1.72, 0.98, 1.15, 1.77, 1.76 and $1.86 \mathrm{mg} / \mathrm{L}$ corresponding to $C_{0}$ of $5,10,15,20,30$ and $50 \mathrm{mg} / \mathrm{L}$ at the contact time of 20, 40, 90, 90, 180 and $180 \mathrm{~min}$ (Fig. 4(b)), respectively. These results demonstrated that all the $\mathrm{Cu}$ (II) $C_{\mathrm{r}}$ can meet with the standard of $2 \mathrm{mg} / \mathrm{L}$ within the initial concentration range of 0 to $50 \mathrm{mg} / \mathrm{L}$. As for lower $C_{0}$ (5 and $10 \mathrm{mg} / \mathrm{L}$ ), even at the initial stage (0 to $40 \mathrm{~min}$ ) the values of $C_{\mathrm{r}}$ were less than $2 \mathrm{mg} / \mathrm{L}$. It was noted here that at the equilibrium time of $180 \mathrm{~min}$, the $\mathrm{Cu}$ (II) $C_{\mathrm{r}}$ was finally determined to be $0.32,0.45,0.65,0.94,1.76$ and $1.86 \mathrm{mg} / \mathrm{L}$ when the initial concentration was $5,10,15,20,30$ and $50 \mathrm{mg} / \mathrm{L}$, respectively.

Descriptions on the adsorption kinetics and isotherm of $\mathrm{Cu}(\mathrm{II})$ onto AL-PEI-CS 2 were given in Text S1. As displayed in Text S1, it showed that experimental data were well fitted by pseudo-second-order kinetic, suggesting the adsorption of $\mathrm{Cu}$ (II) over AL-PEI-CS ${ }_{2}$ was chemisorption. Boyd's film-diffusion model proved the adsorption rate of $\mathrm{Cu}(\mathrm{II})$ onto $\mathrm{AL}-\mathrm{PEI}-\mathrm{CS}_{2}$ was determined by film diffusion. The maximum adsorption capacity $\left(q_{\mathrm{m}}\right)$ of $\mathrm{Cu}(\mathrm{II})$ was obtained as $58 \mathrm{mg} / \mathrm{g}$ by using the Langmuir isothermal model. Table 1 compares the adsorption capacity for different lignin-based adsorbents towards $\mathrm{Cu}$ (II) according to $q_{\mathrm{m}}$ values and the contact time to reach equilibrium, while Table 2 according to the residual concentration of $\mathrm{Cu}$ (II) at equilibrium. As seen from in Table 1, the value of $q_{\mathrm{m}}$ for AL-PEI-CS 2 was higher than adsorbents VI to XII by approximately 1.04, 1.27, 1.36, 3.25, 6.34, 6.87 and 207 times, respectively. It was observed that $q_{\mathrm{m}}$ of AL-PEI-CS ${ }_{2}$ was lower than adsorbents II to IV, whereas the contact time to reach 
Table 1. The Adsorption Capacity of Different Lignin-based Adsorbents towards Cu(II) According to $q_{m}$ and the Time to Reach Equilibrium.

\begin{tabular}{|c|c|c|c|c|c|}
\hline Adsorbents & $t$ (min) & pH & $T\left({ }^{\circ} \mathrm{C}\right)$ & $q_{\mathrm{m}}(\mathrm{mg} / \mathrm{g})$ & Ref. \\
\hline${ }^{\mathrm{I}} \mathrm{AL}-\mathrm{PEI}-\mathrm{CS}_{2}$ & 180 & 5.0 & 25 & 58 & This work \\
\hline 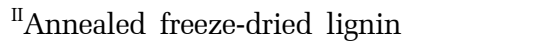 & 2,880 & $n$ & $n$ & 290 & {$[45]$} \\
\hline${ }^{\mathrm{III}}$ Kraft lignin & 2,880 & 4.5 & 25 & 87.1 & [46] \\
\hline${ }^{\mathrm{IV}} \mathrm{Fe}_{3} \mathrm{O}_{4} @ \mathrm{SiO}_{2}-\mathrm{NH}-\mathrm{MFL}$ & 720 & 6.0 & $n$ & 70.6 & {$[22]$} \\
\hline${ }^{\mathrm{v}} \mathrm{N}$-acetyl-L-cysteine-lignin (CFL) & 120 & 6.0 & 15 & 68.7 & [33] \\
\hline${ }^{\mathrm{VI}}$ Aminated epoxy-lignin & 50 & 6.0 & 30 & 55.4 & {$[47]$} \\
\hline${ }^{\mathrm{VII}}$ Lignin-DETA-SO ${ }_{3}$ & 60 & 6.0 & 25 & 45.4 & {$[19]$} \\
\hline 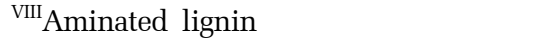 & 360 & 5.5 & 30 & 42.6 & [23] \\
\hline${ }^{\mathrm{IX}}$ Silanization/amination of lignin (SAL) & 150 & 6.7 & 25 & 17.8 & {$[48]$} \\
\hline${ }^{\mathrm{x}}$ Lignocellulosic hydrogel & 1,440 & 6.0 & 25 & 9.14 & [49] \\
\hline${ }^{\mathrm{XI}}$ Kraft lignin & 360 & $n$ & 35 & 8.44 & {$[50]$} \\
\hline XIILignin/chitin films & 2,880 & $n$ & $n$ & 0.28 & {$[51]$} \\
\hline
\end{tabular}
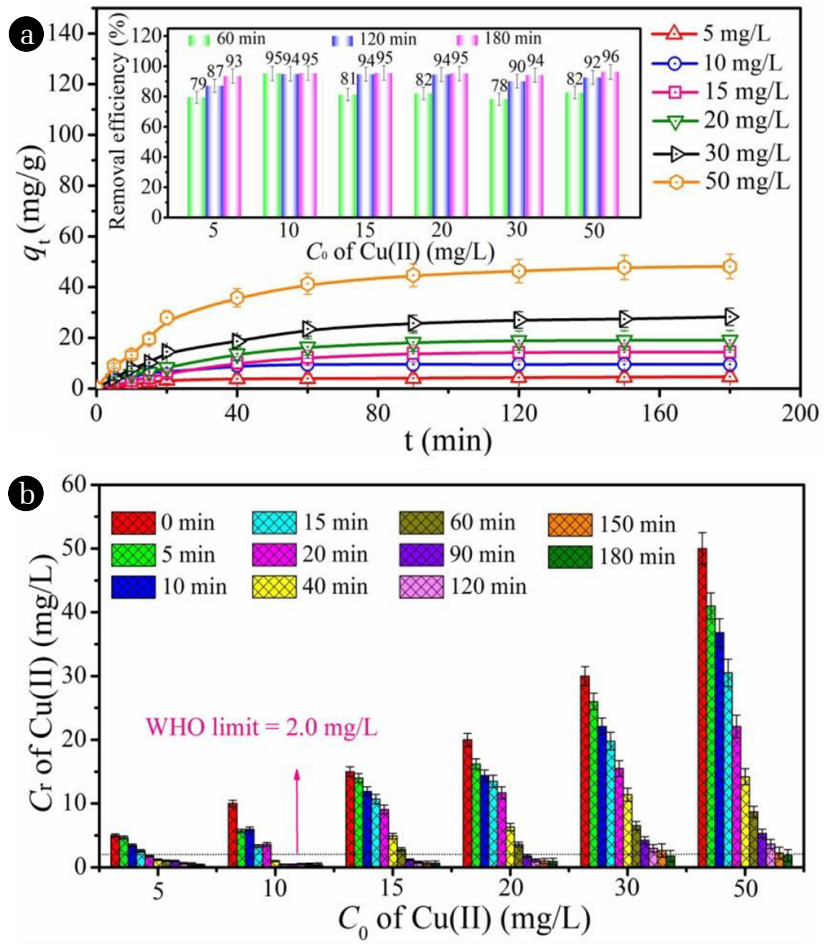

Fig. 4. (a) The influence of contact time on the adsorption of $\mathrm{Cu}(\mathrm{II})$ over AL-PEI-CS ${ }_{2}$ under different initial concentrations (insert: the removal efficiency of $\mathrm{Cu}(\mathrm{II})$ at 60,120 and $180 \mathrm{~min})$; and (b) the values of $\mathrm{C}_{\mathrm{r}}$ at different contact times when $\mathrm{C}_{0}$ of $\mathrm{Cu}$ (II) ranged from 0 to $50 \mathrm{mg} / \mathrm{L}$.

equilibrium for adsorbents II to IV was 4 to 16 times longer than that of AL-PEI-CS 2 . Although adsorbent V presented a shorter equilibrium time and a larger $q_{\mathrm{m}}$ compared to AL-PEI-CS ${ }_{2}$, the value of $C_{\mathrm{r}}$ was as high as $25 \mathrm{mg} / \mathrm{L}$ (Table 2). Under similar initial concentrations of $\mathrm{Cu}(\mathrm{II})$, all the values of $C_{\mathrm{r}}$ for adsorbents II to XII were higher than that of AL-PEI-CS ${ }_{2}$ (Table 2). These results demonstrated that comprehensively considering the values of $q_{\mathrm{m}}$, equilibrium time, and $C_{\mathrm{r}}$, AL-PEI-CS $\mathrm{S}_{2}$ exhibited a relatively ideal application potential.

\subsubsection{Residual concentration of $\mathrm{Cu}(\mathrm{II})$ during the regeneration proc- ess}

In order to evaluate the reusing ability of AL-PEI-CS ${ }_{2}$, a four-adsorption-desorption-cycle was designed. As presented in Fig. S5, the values of $q_{\mathrm{e}}$ was $49.9,49.1,48.9,49.0$ and $48.8 \mathrm{mg} / \mathrm{g}$ for fresh $\mathrm{AL}-\mathrm{PEI}-\mathrm{CS}_{2}$ and the regenerated AL-PEI-CS ${ }_{2}$ at cycles 1 to 4 , respectively. Compared to fresh AL-PEI-CS ${ }_{2}$, the decrease ratio in the $q_{\mathrm{e}}$ value corresponding to cycles 1 to 4 was only $1.6 \%, 2.0 \%$, $1.8 \%$ and $2.2 \%$, respectively. Excitingly, the $\mathrm{Cu}(\mathrm{II}) C_{\mathrm{r}}$ was as low as $1.9,2.1,2.0$ and $2.2 \mathrm{mg} / \mathrm{L}$ for cycles 1 to 4 , basically meeting with the maximum acceptable limit $(2 \mathrm{mg} / \mathrm{L})$ regulated by WHO and Chinese government. These results illustrated that the reusing ability of AL-PEI-CS 2 is acceptable.

\subsection{Adsorption Mechanism}

SEM-EDS exhibits the uptake of Cu(II) by AL-PEI-CS ${ }_{2}$ (Fig. S6). FT-IR spectra of AL-PEI-CS ${ }_{2}$ and AL-PEI-CS ${ }_{2}-\mathrm{Cu}(\mathrm{II})$ complexes were displayed in Fig. 5(a). Compared to AL-PEI-CS ${ }_{2}$, the peaks centered at 1,662 $\left(-\mathrm{NH}_{2}\right)$ and $855 \mathrm{~cm}^{-1}$ (C-S) weakened for AL-PEI-CS ${ }_{2}-\mathrm{Cu}$ (II) complexes, indicating that the groups of $-\mathrm{NH}_{2}$ and -CSS- were responsible for the uptake of $\mathrm{Cu}(\mathrm{II})$. XPS technology was employed to further confirm the adsorption mechanism. Fig. 5(b) presents that one peak of $\mathrm{Cu} 2 \mathrm{p}$ for AL-PEI-CS $\mathrm{CS}_{2} \mathrm{Cu}(\mathrm{II})$ complexes was recorded. The characteristic peaks of $\mathrm{Cu} 2 \mathrm{p}$ centered at 951.8 and $931.9 \mathrm{eV}$ were assigned to $\mathrm{Cu} 2 \mathrm{p}^{1 / 2}$ and $\mathrm{Cu} 2 \mathrm{p}^{3 / 2}$ (Fig. 5(c)) [52], respectively. The high-resolution spectra for $\mathrm{S} 2 \mathrm{p}$ displayed that the binding energy of $\mathrm{C}=\mathrm{S}$ and $\mathrm{C}-\mathrm{S}$ groups in AL-PEI-CS $\mathrm{C}_{2}$ shifted from $163.2 \mathrm{eV}$ to $162.8 \mathrm{eV}$ and $168.6 \mathrm{eV}$ to $167.2 \mathrm{eV}$ in AL-PEI-CS ${ }_{2}$-Cu(II) complexes (Fig. 5(d)). A new peak of $168.7 \mathrm{eV}$ emerged in AL-PEI-CS ${ }_{2}-\mathrm{Cu}(\mathrm{II})$ complexes, which was attributed to $\mathrm{S}-\mathrm{Cu}$. These results demonstrated that $\mathrm{S}$ atom of the -CSS- group in AL-PEI-CS ${ }_{2}$ accounted for binding with $\mathrm{Cu}(\mathrm{II})$ [53]. The binding energies of $\mathrm{N}$ 1s for $-\mathrm{N}-\mathrm{CS}_{2}(403.9 \mathrm{eV})$ and $-\mathrm{NH} / \mathrm{NH}_{2}$ groups (399.5 $\mathrm{eV}$ ) carried by AL-PEI-CS ${ }_{2}$ were observed to be shifted to 400.9 $\mathrm{eV}$ and $399.2 \mathrm{eV}$ in AL-PEI-CS ${ }_{2}$-Cu(II) complexes (Fig. 5(e)), respectively, which may be due to the groups of C-N and $-\mathrm{NH} /-\mathrm{NH}_{2}$ interacted with $\mathrm{Cu}(\mathrm{II})$ [19]. As shown in Fig. 5(f), the peaks at 532.6 and $531.7 \mathrm{eV}$ (correspondingly assigned to the functional groups of $\mathrm{C}-\mathrm{O}$ and $-\mathrm{OH}$ ) moved to 532.4 and $531.2 \mathrm{eV}$. Moreover, 

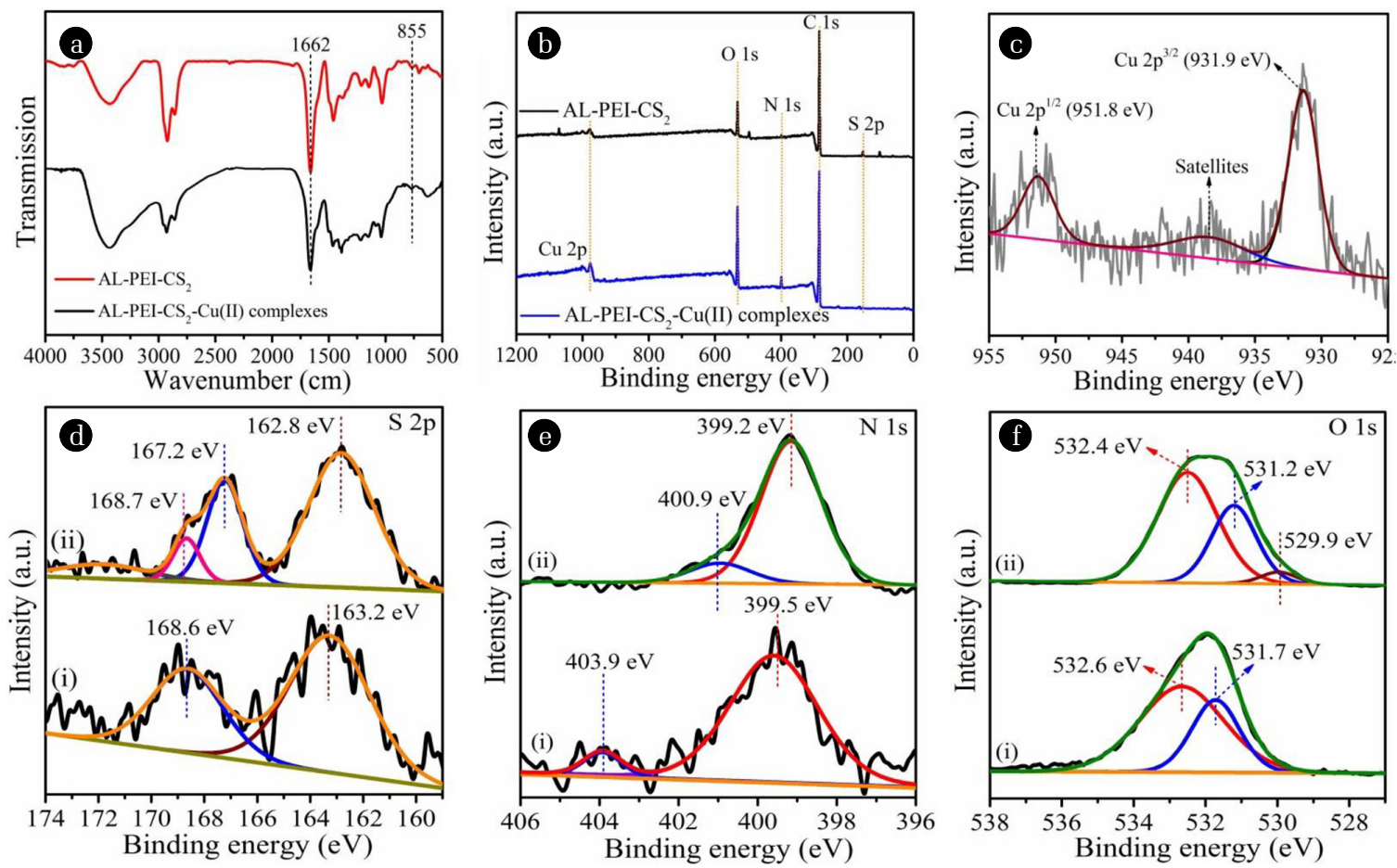

Fig. 5. (a) FT-IR spectra of AL-PEI-CS $S_{2}$ and $A L-P E I-C S_{2}-C u(I I)$ complexes; (b) full scan survey XPS spectra of AL-PEI-CS $/ \mathrm{AL}^{-P E I-C S_{2}-C u(I I)}$ Complexes; (c) high resolution spectra of $\mathrm{Cu} 2 \mathrm{p}$ for $\mathrm{AL}-\mathrm{PEI}-\mathrm{CS}_{2}-\mathrm{Cu}$ (II) complexes; high resolution spectra of $\mathrm{S} 2 \mathrm{p}(\mathrm{d}), \mathrm{N}$ 1s (e) and $\mathrm{O}$ 1s (f) of $\mathrm{AL}-\mathrm{PEI}-\mathrm{CS}_{2} / \mathrm{AL}-\mathrm{PEI}-\mathrm{CS}_{2}-\mathrm{Cu}(\mathrm{II})$ complexes (i: $\mathrm{AL}-\mathrm{PEI}-\mathrm{CS}_{2}$ and ii: $\mathrm{AL}-\mathrm{PEI}-\mathrm{CS}_{2}-\mathrm{Cu}(\mathrm{II})$ complexes).

Table 2. The Adsorption Capacity of Different Lignin-based Adsorbents towards $\mathrm{Cu}$ (II) According to the Residual Concentration of $\mathrm{Cu}$ (II) at Equilibrium

\begin{tabular}{|c|c|c|c|c|c|}
\hline Adsorbents & $C_{0}(\mathrm{mg} / \mathrm{L})$ & $t$ (min) & Dosage (g/L) & Functional groups & $C_{\mathrm{r}}(\mathrm{mg} / \mathrm{L})$ \\
\hline${ }^{\mathrm{I}} \mathrm{AL}-\mathrm{PEI}-\mathrm{CS}_{2}$ & 50 & 180 & 1.0 & $-\mathrm{OH},-\mathrm{NH},-\mathrm{NH}_{2},-\mathrm{CSS}-$ & 1.86 \\
\hline${ }^{\mathrm{III}}$ Kraft lignin & 65 & 2,880 & 4.0 & $-\mathrm{OH},-\mathrm{SO}_{3^{-}}$ & 2.54 \\
\hline${ }^{\mathrm{XI}}$ Kraft lignin & 63.5 & 360 & 5.0 & $-\mathrm{OH}$ & 23.81 \\
\hline${ }^{\mathrm{IX}}$ Silanization/amination of lignin (SAL) & 55 & 150 & 2.0 & $-\mathrm{OH},-\mathrm{NH}_{2},-\mathrm{Si}-\mathrm{O}-$ & 25 \\
\hline${ }^{\mathrm{VI}}$ Aminated epoxy-lignin & 50 & 50 & 2.5 & $-\mathrm{OH},-\mathrm{COOH},-\mathrm{NH}_{2}$ & 15 \\
\hline VIIIAminated lignin & 50 & 360 & 0.2 & $-\mathrm{OH},-\mathrm{NH}_{2}$ & 45.6 \\
\hline${ }^{\mathrm{IV}} \mathrm{Fe}_{3} \mathrm{O}_{4} @ \mathrm{SiO}_{2}-\mathrm{NH}-\mathrm{MFL}$ & 50 & 720 & 0.5 & $-\mathrm{OH},-\mathrm{COOH}$ & 20.0 \\
\hline VIILignin-DETA-SO ${ }_{3}$ & 50 & 60 & 3.0 & $-\mathrm{OH},-\mathrm{NH},-\mathrm{NH}_{2},-\mathrm{SO}_{3}-$ & 14.02 \\
\hline${ }^{\mathrm{V}} \mathrm{N}$-acetyl-L-cysteine-lignin (CFL) & 50 & 120 & 2.0 & $-\mathrm{OH},-\mathrm{COOH},-\mathrm{NH}$ & 25 \\
\hline 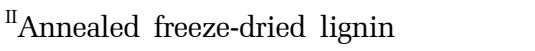 & 30 & 2,880 & 0.05 & $-\mathrm{OH},-\mathrm{COOH}$ & 13.1 \\
\hline${ }^{\mathrm{x}}$ Lignocellulosic hydrogel & 6.4 & 1,440 & 4.0 & $-\mathrm{OH},-\mathrm{COOH}$ & 3.84 \\
\hline XIILignin/chitin films & 4.0 & 2,880 & $n$ & $-\mathrm{OH},-\mathrm{NH}$ & 3.12 \\
\hline
\end{tabular}

a new peak at $529.9 \mathrm{eV}$ was assigned to $\mathrm{O}-\mathrm{Cu}$. These results indicated that the oxygen containing functional groups participated in the adsorption process. Combined FT-IR with XPS spectra, it can be concluded that the groups of $-\mathrm{OH},-\mathrm{NH}_{2},-\mathrm{NH}, \mathrm{C}-\mathrm{N}$, and -CSScarried by AL-PEI-CS ${ }_{2}$ served as the adsorption sites.

In order to explain the advantage of AL-PEI-CS ${ }_{2}$ over other lignin-based adsorbents presented in Table 2, the functional groups of these materials were given. An obvious difference lies in the existence of -CSS- group for AL-PEI-CS 2 . In our previous study [37], a kind of modified alkaline lignin (FLAL) was prepared, in which alkaline lignin was used as raw material, and carbon disulfide
$\left(\mathrm{CS}_{2}\right)$ was employed as the modifier. The functional groups of -CSScarried by FLAL was proved to be the primary adsorption site for $\mathrm{Pb}(\mathrm{II})$ and $\mathrm{Cu}(\mathrm{II})$. According to the traditional theory [43, 44], the adsorption ability of FLAL towards $\mathrm{Pb}$ (II) should be higher than $\mathrm{Cu}(\mathrm{II})$ as the hydration radius of $\mathrm{Pb}(\mathrm{II})(4.01 \AA)$ is less than $\mathrm{Cu}(\mathrm{II})(4.19 \AA)$. It is well known that lower hydration radius is beneficial to adsorption. In contrast, FLAL exhibited better removal performance for $\mathrm{Cu}(\mathrm{II})$ than for $\mathrm{Pb}(\mathrm{II})$. The reason was that the bond energy between the functional group of -CSS- and $\mathrm{Cu}(\mathrm{II})$ was lower than that of $\mathrm{Pb}(\mathrm{II})$ based on DFT calculations. Thus, we pointed out that not only the physio-chemical property of sorbate 
but also the functional group of adsorbent determines the adsorption performance. On the basis of our previous research, we hypothesized that it might be the existence of the -CSS- group that makes $\mathrm{AL}-\mathrm{PEI}-\mathrm{CS}_{2}$ work well with the residual concentration of $\mathrm{Cu}(\mathrm{II})$ meeting with the standard of $2 \mathrm{mg} / \mathrm{L}$ under variously operating conditions.

\section{Conclusions}

In this work, the adsorbent AL-PEI-CS 2 was used to remove copper from aqueous solution and its performance was evaluated based on the residual concentration $\left(C_{\mathrm{r}}\right)$ of $\mathrm{Cu}$ (II) under various operating conditions including solution $\mathrm{pH}$, coexisting cations, contact time, and the initial concentrations of $\mathrm{Cu}(\mathrm{II})$. When the solution $\mathrm{pH}$ ranged from 5.03 to 5.65 , the values of $C_{\mathrm{r}}$ were measured to be 1.2 and $1.0 \mathrm{mg} / \mathrm{L}$, lower than the discharged standard of $2.0 \mathrm{mg} / \mathrm{L}$ regulated by WHO and Chinese government. Under the situation of $\mathrm{Cu}$ (II) coexisting with $\mathrm{K}(\mathrm{I}), \mathrm{Na}(\mathrm{I}), \mathrm{Ca}(\mathrm{II})$ and $\mathrm{Mg}(\mathrm{II})$, the values of $C_{\mathrm{r}}$ were determined to be 1.96 (or 2.06), 1.53 (2.18), 1.97 (1.71) and 1.55 (2.53) $\mathrm{mg} / \mathrm{L}$ when the initial concentrations of the four cations were 50 (or 100 ) $\mathrm{mg} / \mathrm{L}$, respectively. At the contact time of $180 \mathrm{~min}$, the values of $C_{\mathrm{r}}$ were $0.32,0.45,0.65,0.94,1.76$ and $1.86 \mathrm{mg} / \mathrm{L}$ corresponding to the initial copper concentrations of 5, 10, 15, 20, 30 and $50 \mathrm{mg} / \mathrm{L}$, respectively. Even AL-PEI-CS ${ }_{2}$ was regenerated for four times, the values of $C_{\mathrm{r}}$ were as low as 1.9, 2.1, 2.0 and $2.2 \mathrm{mg} / \mathrm{L}$ for cycles 1, 2, 3 and 4 at the initial concentration of $\mathrm{Cu}(\mathrm{II})$ of $51 \mathrm{mg} / \mathrm{L}$ and contact time of $180 \mathrm{~min}$. Compared to other lignin-based adsorbents based on $q_{\mathrm{m}}$, equilibrium time and $C_{\mathrm{r}}$ at equilibrium, AL-PEI-CS $\mathrm{S}_{2}$ exhibited higher application potential to the treatment of $\mathrm{Cu}(\mathrm{II})-$ loaded wastewater. Adsorption mechanism revealed that $-\mathrm{OH},-\mathrm{NH}_{2},-\mathrm{NH}, \mathrm{C}-\mathrm{N}$ and -CSS- contributed to the uptake of copper ions.

\section{Acknowledgments}

Key R\&D Program of Shaanxi Province (2019SF-253) and the Natural Science Foundation of Chongqing (cstc2020jcyj-msxmX0763) supported this work. We would also like to thank the Instrument Analysis Center of Xi'an Jiaotong University for its support. It is also a great pleasure to obtain valuable comments from editor and anonymous.

\section{Author Contributions}

C.L.Z (Associate Professor) contributed to conceptualization, review, editing and funding acquisition. Q.R.W (Ph.D. student) conducted conceptualization, investigation, formal analysis and original draft. Y.J.D (Senior Engineer) was responsible for data curation. B.Z (Professor) offered funding acquisition. Y.Y.Z (Ph.D. Assistant Professor) collected resources. T.C.Z (Professor) was in charge of sources.

\section{References}

1. Schwarzenbach RP, Escher BI, Fenner K, et al. The challenge of micropollutants in aquatic systems. Science 2006;313: 1072-1077.

2. Yao ZY, Qi JH, Wang LH. Equilibrium, kinetic and thermodynamic studies on the biosorption of $\mathrm{Cu}$ (II) onto chestnut shell. J. Hazard. Mater. 2010;174:137-143.

3. Zhang H, Omer AM, Hu ZH, et al. Fabrication of magnetic bentonite/carboxymethyl chitosan/sodium alginate hydrogel beads for $\mathrm{Cu}$ (II) adsorption. Int. J. Biol. Macromol. 2019;135: 490-500.

4. Karim Z, Claudpierre S, Grahn M, et al. Nanocellulose based functional membranes for water cleaning: Tailoring of mechanical properties, porosity and metal ion capture. J. Membr. Sci. 2016;514:418-428.

5. Jung KW, Lee SY, Choi JW, et al. A facile one-pot hydrothermal synthesis of hydroxyapatite/biochar nanocomposites: Adsorption behavior and mechanisms for the removal of copper(II) from aqueous media. Chem. Eng. J. 2019;369:529-541.

6. China Sewage Treatment Engineering Network. Treatment technology of copper(II)-containing wastewater [Internet]. Carlton: China Sewage Treatment Engineering Network; c2019 [cited February 2021]. Available from: https://www.dowater.com/ jishu/2019-11-07/1097697.html.

7. Pang FM, Kumar P, Teng TT, et al. Removal of lead, zinc and iron by coagulation-flocculation. J. Taiwan Inst. Chem. Eng. 2011;42:809-815.

8. Esalah J, Husein MM. Removal of heavy metals from aqueous solutions by precipitation-filtration using novel organo-phosphorus ligands. Sep. Sci. Technol. 2008;43:3461-3475.

9. Silva JE, Paiva AP, Soares D, et al. Solvent extraction applied to the recovery of heavy metals from galvanic sludge. J. Hazard. Mater. 2005;120:113-118.

10. Mohsen-Nia M, Montazeri P, Modarress H, et al. Removal of $\mathrm{Cu}^{2+}$ and $\mathrm{Ni}^{2+}$ from wastewater with a chelating agent and reverse osmosis processes. Desalination 2017,217:276-281.

11. Lo SF, Wang SY, Tsai M), et al. Adsorption capacity and removal efficiency of heavy metal ions by Moso and Ma bamboo activated carbons. Chem. Eng. Res. Des. 2012,90:1397-1406.

12. Bailey SE, Olin TJ, Bricka RM, et al. A review of potentially low-cost sorbents for heavy metals. Water Res. 1999;33:2469-2479.

13. Khin MM, Nair AS, Babu VJ, et al. A review on nanomaterials for environmental remediation. Energy Environ. Sci. 2012;5: 8075-8109.

14. Klapiszewski L, Siwinska-Stefanska K, Kolodynska D. Development of lignin based multifunctional hybrid materials for $\mathrm{Cu}(\mathrm{II})$ and $\mathrm{Cd}(\mathrm{II})$ removal from the aqueous system. Chem. Eng. J. 2017;330:518-530.

15. Vanholme R, Demedts B, Morreel K, et al. Lignin biosynthesis and structure. Plant Physiol. 2010;153:895-905.

16. Ragauskas AJ, Beckham GT, Biddy MJ, et al. Lignin valorization: improving lignin processing in the biorefinery. Science 2014;344:709.

17. Supanchaiyamat N, Jetsrisuparb K, Knijnenburg JTN, et al. Lignin materials for adsorption: Current trend, perspectives and opportunities. Bioresource Technol 2019;272:570-581.

18. Thakur VK, Thakur MK, Raghavan P, et al. Progress in green polymer composites from lignin for multifunctional applica- 
tions: A review. ACS Sustainable Chem. Eng. 2014;2:1072-1092.

19. Ge Y, Li Z, Kong Y, et al. Heavy metal ions retention by bi-functionalized lignin: Synthesis, applications, and adsorption mechanisms. J. Ind. Eng. Chem. 2014;20:4429-4436.

20. Ge YY, Li ZL. Application of lignin and its derivatives in adsorption of heavy metal ions in water: A review. ACS Sustainable Chem. Eng. 2018;6:7181-7192.

21. Merdy P, Guillon E, Aplincourt M, et al. Copper sorption on a straw lignin: Experiments and EPR characterization. J. Colloid. Interface. Sci. 2002;245:24-31.

22. Zhang YC, Ni SZ, Wang XJ, et al. Ultrafast adsorption of heavy metal ions onto functionalized lignin-based hybrid magnetic nanoparticles. Chem. Eng. J. 2019;372:82-91.

23. Xu J, Zhu SY, Liu P, et al. Adsorption of $\mathrm{Cu}(\mathrm{II})$ ions in aqueous solution by aminated lignin from enzymatic hydrolysis residue. RSC Adv. 2017;7:44751-44758.

24. Chakraborty S, Tare, V. Role of various parameters in synthesis of insoluble agrobased xanthates for removal of copper from wastewater. Bioresour. Technol. 2006;97:2407-2413.

25. Wang QR, Zheng CL, Shen ZX, et al. Polyethyleneimine and carbon disulfide co-modified alkaline lignin for removal of $\mathrm{Pb}^{2+}$ ions from water. Chem. Eng. J. 2019;359:265-274.

26. Jin C, Zhang XY, Xin JN, et al. Clickable synthesis of 1,2,4-triazole modified lignin-based adsorbent for the selective removal of Cd(II). ACS Sustainable Chem. Eng. 2017;5:4086-4093.

27. Liu Y, Hu TJ, Wu ZP, et al. Study on biodegradation process of lignin by FT-IR and DSC. Environ. Sci. Pollut. R. 2014;21: 14004-14013.

28. Deng SB, Ting YP. Characterization of PEI-modified biomass and biosorption of $\mathrm{Cu}(\mathrm{II}), \mathrm{Pb}(\mathrm{II})$ and $\mathrm{Ni}(\mathrm{II})$. Water Res. 2005;39: 2167-2177.

29. Liu C, Jin RN, Ouyang XK, et al. Adsorption behavior of carboxylated cellulose nanocrystal-polyethyleneimine composite for removal of $\mathrm{Cr}(\mathrm{VI})$ ions. Appl. Surf. Sci. 2017;408:77-87.

30. Desseyn HO, Fabretti AC, Forghieri F, et al. Isotopic infrared study of some nickel (II) and copper (II) complexes containing heterocyclic dithiocarbamate ligands. Spectrochim. Acta, Part A 1985;41:1105-1108.

31. Matlock MM, Howerton BS, Henke KR, et al. A pyridine-thiol ligand with multiple bonding sites for heavy metal precipitation. J. Hazard. Mater. 2001;82:55-63.

32. Lou ZN, Xiao X, Huang MN, et al. Acrylic acid-functionalized metal-organic frameworks for Sc(III) selective adsorption. ACS Appl. Mater. Inter. 2019;11:11772-11781.

33. Jin C, Zhang XY, Xin JN, et al. Thiol-ene synthesis of cysteine-functionalized lignin for the enhanced adsorption of $\mathrm{Cu}(\mathrm{II})$ and $\mathrm{Pb}(\mathrm{II})$. Ind. Eng. Chem. Res. 2018;57:7872-7880.

34. Battistoni C, Giuliani AM, Paparazz E, et al. Platinum complexes of the methyl-esters of dithiocarbazic acid and 3-phenyldithiocarbazic acid. J. Chem. Soc. Dalton Trans. 1984;7:1293-1299.

35. Luo K, Zhang JG. Status quo of the disposal of acidic mining waste water. Res. Environ. Eng. 2005;19:45-49 (in Chinese).

36. Zhang WL, Fu R, Wang L, et al. Rapid removal of ammonia nitrogen in low-concentration from wastewater by amorphous sodium titanate nano-particles. Sci. Total Environ. 2019;668:
815-824.

37. Wang QR, Zheng CL, Cui W, et al. Adsorption of $\mathrm{Pb}^{2+}$ and $\mathrm{Cu}^{2+}$ ions on the $\mathrm{CS}_{2}$-modified alkaline lignin. Chem. Eng. J. 2020;391.

38. Todorciuc T, Bulgari L, Popa VI. Adsorption of $\mathrm{Cu}(\mathrm{II})$ from aqueous solution on wheat straw lignin: Equilibrium and kinetic studies. Cellul. Chem. Technol. 2015;49:439-447.

39. Zhou JX, Ding YJ, Zeng GX, et al. Major ion chemistry of surface water in the upper reach of Shule River basin and the possible controls. Environ. Sci. 2014;35:1-10 (In Chinese).

40. Liu W, Wang T, Borthwick AGL, et al. Adsorption of $\mathrm{Pb}^{2+}$, $\mathrm{Cd}^{2+}, \mathrm{Cu}^{2+}$ and $\mathrm{Cr}^{3+}$ onto titanate nanotubes: Competition and effect of inorganic ions. Sci. Total Environ. 2013;456:171-180.

41. Zhang W, Song JY, He QL, et al. Novel pectin based composite hydrogel derived from grapefruit peel for enhanced $\mathrm{Cu}(\mathrm{II})$ removal. J. Hazard. Mater. 2020;384:121445.

42. Hofer TS, Hunenberger PH. Absolute proton hydration free energy, surface potential of water, and redox potential of the hydrogen electrode from first principles: QM/MM MD free-energy simulations of sodium and potassium hydration. J. Chem. Phys. 2018;148:1-29.

43. Noyes RM. Thermodynamics of ion hydration as a measure of effective dielectric properties of water. J. Am. Chem. Soc. 1962;84:513-522.

44. Cheng TW, Lee ML, Ko MS, et al. The heavy metal adsorption characteristics on metakaolin-based geopolymer. Appl. Clay. Sci. 2012;56:90-96.

45. Chen FG, Shahabadi SIS, Zhou D, et al. Facile preparation of cross-linked lignin for efficient adsorption of dyes and heavy metal ions. React. Funct. Polym. 2019;143:1-6.

46. Mohan D, Pittman CU, Steele PH. Single, binary and multi-component adsorption of copper and cadmium from aqueous solutions on Kraft lignin-a biosorbent. J Colloid Interf Sci 2006;97:489-504.

47. Liu X, Zhu H, Qin C, et al. Adsorption of heavy metal ion from aqueous single metal solution by aminated epoxy-lignin. BioResources 2013;8:2257-2269.

48. An L, Si CL, Bae JH, et al. One-step silanization and amination of lignin and its adsorption of Congo red and $\mathrm{Cu}(\mathrm{II})$ ions in aqueous solution. Int. J. Biol. Macromol. 2020;159:222-230.

49. Shen XP, Xi YJ, Wang QW, et al. Enhanced heavy metal adsorption ability of lignocellulosic hydrogel adsorbents by the structural support effect of lignin. Cellulose 2019;26:4005-4019.

50. Sciban M, Klasnja M. Study of the adsorption of copper(II) ions from water onto wood sawdust, pulp and lignin. Adsorpt Sci. Technol. 2004;22:195-206.

51. Duan YQ, Freyburger A, Kunz W, et al. Lignin/chitin films and their adsorption characteristics for heavy metal ions. ACS Sustain Chem. Eng. 2018;6:6965-6973.

52. Zhu Y, Fan WH, Zhou TT, et al. Removal of chelated heavy metals from aqueous solution: A review of current methods and mechanisms. Sci. Total Environ. 2019;678:253-266.

53. Xiao D, Ding W, Zhang JB, et al. Fabrication of a versatile lignin-based nano-trap for heavy metal ion capture and bacterial inhibition. Chem. Eng. J. 2019;358:310-320. 